\title{
RUSSIAN HUNTING MUSIC
}

\section{By JAROSLAW DE ZIELINSKI}

$I^{\mathrm{T}}$

T WAS under Augustus I, and his son Augustus II the Strong, the "Saxon Man of Sin," as Carlyle called him, that Dresden, an old Slavonic city which Herder has since defined as "The German Florence," became known to the world. Here lived in 1746 one Anton Josef Hampl, attached to the reigning house as court and opera musician, and this man, scarcely ever noticed in our musical biographies, discovered in 1760, accidentally, that the natural tones of the French Horn could be lowered half a step by inserting the hand into the bell! Five years after this discovery the horn's beauty of timbre was demonstrated in Paris when Jean Joseph Rodolphe, a remarkable musician of his day, played the horn concertante part to the air "Amour dans ce riant bocage" by Pascal Boyer, as sung by the famous tenor, Josef Legros.

Having heard of great possibilities in the imperial city of St. Petersburg, now Petrograd, another French Horn player, Johann A. Maresch, unknown but soon to become famous, decided to go there and seek fortune. Maresch was a native of Bohemia, born in 1719 at Chotieborz, and he showed from his youngest days a remarkable aptitude for music, especially the French Horn, a favorite instrument at that time with the Czechs. He had the earnest support of relatives and friends, for the times were strenuous and the Prussians were pounding their way into Prague. So with his instrument under the arm, Johann A. got to Petrograd in 1744, just about the same time that Lestocq, the Franco-German adventurer, actual Counsellor of State and first Court Physician to the last of the Romanoffs, Elizabeth I, had left for Kieff, accompanying his mistress who had been now Empress of Russia for three years.

Maresch was not slow in pushing himself forward, and in a short time became known to Alexis Petrovitch Bestousheff, at one time a protégé of Lestocq, but later one of his most bitter enemies. Bestousheff was the descendant of a certain Gabriel Best from the county of Kent, England, who had come to Russia in 1413, a hundred and forty years in advance of Richard Chancellor whose landing at Archangel took place in 1553. Most of 
the Englishmen who went to Russia in thase days were either traders or craftsmen; one in particular, John Villiers, unknown to the world at large, built in Moscow the famous tower, and his name in consequence was corrupted into Ivan Veliky, that is, "John the Great!"

Alexis Petrovitch Bestousheff had been vice-chancellor a couple of years, and though destined to be all-powerful, he was more anxious to please his mistress who often spoke of her unbounded physical and moral repulsion toward him. Entering in 1744 upon the exalted office of Grand Chancelor, a festival in honor of the Empress was in order at the chancelery. Maresch was one of the soloists, and Elizabeth was so pleased with his art that she engaged him forthwith, conferring upon him also the title of chamber musician.

Prior to this event the court's musical favorite had been a peasant from Little Russia, a young man whose bass voice literally made the windows rattle in the diminutive country church where he sang Sundays. The way this singer was discovered is told in an interesting fashion by Colonel Feodor Stepanovitch Vishnievsky who had been sent to Hungary to buy wines for the cellar of Anna Ivanovna, niece of Peter the Great. On his return journey, crossing Ukraina, the colonel stopped at the village Lemiohy; it was Sunday, and like all good orthodor Russians, Feodar Stepanovitch went to church, where he was startled with the tremendous bass voice of a young peasant, Alexy Gregoryevitch by name. The youth's father was a registered Cossack, and an inveterate drunkard who beat the boy whenever a chance offered, and one time tried to kill him by throwing an axe at his head. This old reprobate's name was Gregory Yakovlovitch, but everyone called him "Razoum" (understanding), for when drunk he would persist in saying: "Ha! what a head, what knowledge!" Of course, the colonel carried off the young man and presented him to Elizabeth, for which he was rewarded with rank of majorgeneral and an exalted position at court. In love with the beautiful voice and handsome peasant, Elizabeth conferred upon Alexis Gregoryevitch, later Razoumovsky, the title of chamber musician, upon which he promptly lost his voice.

Of these affections, so generously bestowed by the Tsarina, Johann A. Maresch found himself at times a beneficiary, viewed with a jealous eye by Bestousheff, Lestocq and Naryshkin, not to mention Razoumovsky. Of course, Elizabeth flattered herself that Russia teeming with imitations was Europe, and while she corrected to a certain extent the morals of her clergy, she and her 
court led in scandals the other courts of Europe; Saxony, Prussia, Denmark, England, Spain and Portugal, in which the respective rulers set the example of most licentious manners. Many writers have tried to saddle this excessive freedom of morals on French society, but indeed such were the doings of the Russian and other courts that Versailles could have easily passed for the first asylum of virtue.

Directly under the orders of the Marshal of the Court, Simon Kirillovitch Naryshkin, who had also the direction of the Imperial Chapel and Theatre, Maresch was charged with the improvement of the very primitive Russian Hunting Horn, which must not be confounded with what we call a Hunting Horn, Flugel Horn or Post Horn; really it is but a simple conical tube of brass bent the fourth of a circle at its smaller end, as in the accompanying picture. There was much to accomplish, and the first thing that

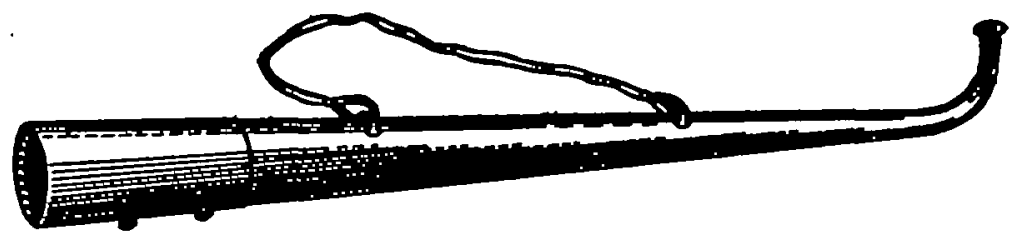

Maresch undertook was the tuning of those instruments, so crudely constructed by tinsmiths that their pitch differed at times a whole step. After establishing a uniform pitch, he had the instruments tuned in thirds, fifths and octaves, so that when united they could give the major chord of $D(D, F \#, A, D)$.

When hunting, sixteen horn-blowers were employed; these were peasants who had no idea of music, but when they met each one would sound his horn, and as each horn could give but one sound, the intervals of the chord of $D$ major were heard, or the complete chord, according to the combination of the moment. Some enthusiastic admirers of Maresch have acclaimed this fanfare of horns to have been his glorious invention, dating from 1751, but as far back as the "Well-beloved" Louis XIV, many fanfares for the hunt were composed and selected by that monarch with the help of his master of the hunt, Monsieur de Dampierre.

Of course, the very first result obtained by Maresch delighted Naryshkin, the ex-betrothed of the Empress, to such an extent that he conceived the brilliant idea of using horns for the rendition of instrumental ensemble. One can imagine the horror with which poor Maresch, chamber musician of Elizabeth I, was 
overwhelmed when this extraordinary notion was communicated to him, for, while the peasants combined under his orders knew how to blow individually into their instruments, their musical knowledge was there at an end. Nevertheless, he did not shirk the idea, and formulated a way of making each one hold his part in an ensemble without teaching him music for that purpose; indeed, such a course would have presented insurmountable difficulties.

The first move was the construction of twenty-five horns, tuned like the pipes of an organ and able to produce two complete chromatic octaves. The next step was to invent conventional signs that would replace the usual notation. Of course, that was easy, especially so because of the fact that each horn could produce but one sound; this turned the pseudo-instrumentalist practically into a machine; the only remaining difficulty was to teach him how to count the measures and rests! So each note was written the same as a quarter note, while silence was indicated by $|-|$, which sign corresponded with our quarter rest; furthermore, each part had at the beginning the name of the note and octave to which it belonged. The movement was developed during the study of the piece, while in view of the tremendous sonority of the band, Maresch had to use a bell to indicate the measure.

There was much profit to Maresch in what he taught, for in calculating how to teach others, he taught himself, and the instrumental ensemble that he chose to be accompanied by these hunting horns he made up of twelve horns, two trumpets and two post horns. The first four pieces prepared for this band were written in $F$ major, and the twelve horns were divided as follows: one in C\# (alt), which like the $C$ or D horns in alt was seldom if ever used; these horns present a meager timbre of very poor quality, and examples of their use do not exist in the scores of classic writers; six horns in D, one in E, two in A and two in C. In place of kettle-drums he used two machines made up in the form of a drum; each one had four bells tuned in major third, perfect fifth and octave; when set in motion one machine would give the tonic chord of $D$ major (D, F\#, A, D), the other that of dominant chord (A, C\#, E, A).

This strange instrumental combination lasted a year, when Naryshkin began to show dissatisfaction with the difficulty of keeping together so large a number of foreign horn-players, in order to combine them with the hunting horns; in truth, the financial charge was at the bottom of all trouble, for these peripatetic musicians, not particularly overgifted, knew how to 


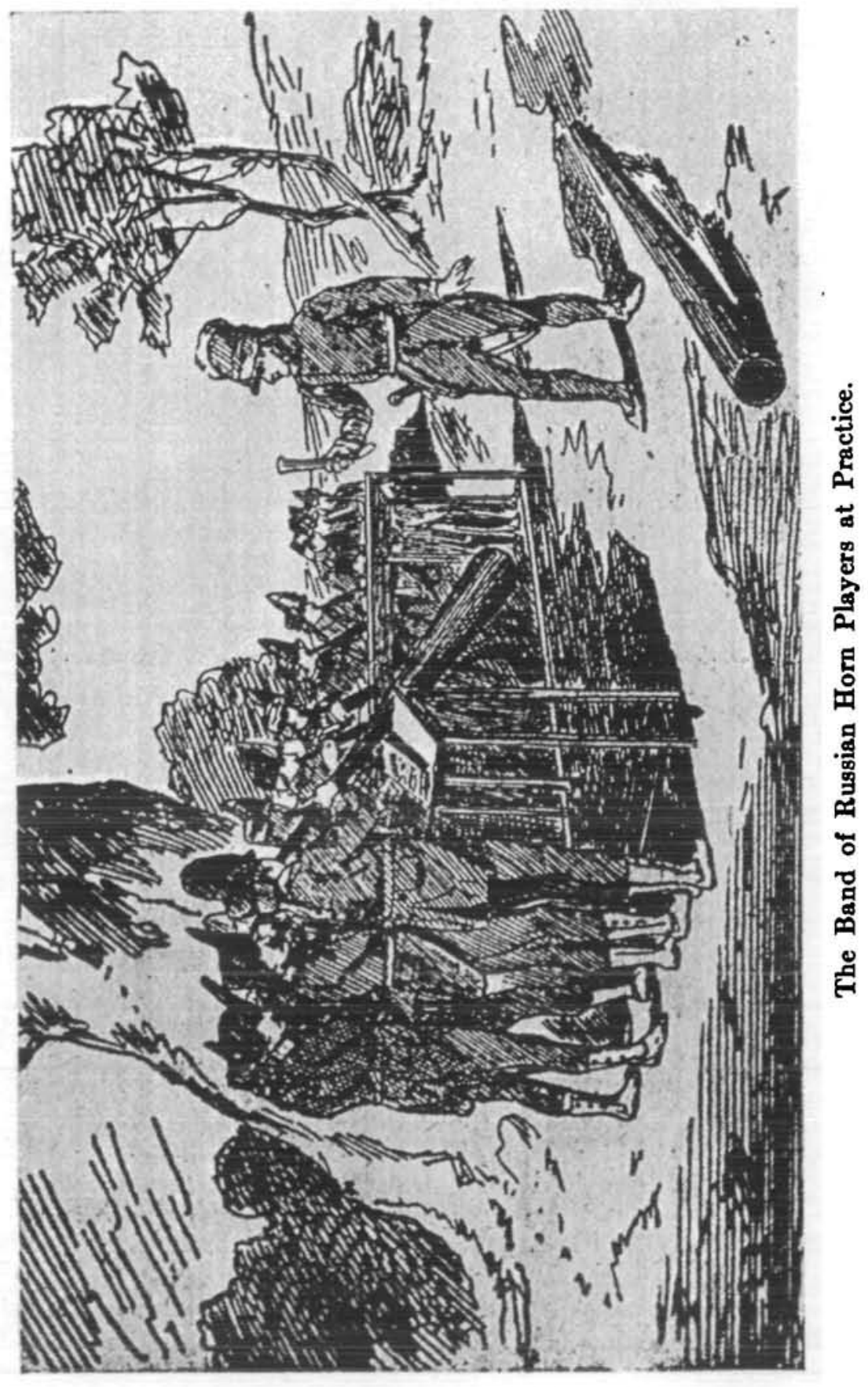


extort big pay and undeserved considerations. Otherwise Naryshkin was quite encouraged with the success of these first efforts, and asked Maresch to teach twelve hunters to play the horn, giving him a year in which to accomplish the task. Overwhelmed by this new fantasy of the Grand Marshal, and well aware of the insurmountable difficulties to overcome in teaching the moujycks that were detailed for such instruction, Maresch worried greatly and finally decided that the best way would be to use the hunting horns alone. Such was the real origin of Russian Hunting Music.

First, he wrote two easy pieces in three parts, which were put into practice at once at a tremendous expenditure of time, labor and patience; but the reward was near. At a banquet to which he was invited, Naryshkin was again in a faultfinding mood; this time because Maresch was not making a show of hurry to carry out his wishes. This was the cue, and bringing together his pupils who had been in waiting, Maresch made their ensemble playing reveal what he had accomplished, for he made no use of the foreign horn-players. Of course, the success was beyond all expectation; Simon Kirillovitch Naryshkin folded Maresch in his arms and declared the combination by far superior to the mixed ensemble of hunting horns and other horns whose tones were too weak for the former. There was haste in the séance that followed, and it was decided without much ado, that henceforth the hunting horns would form an ensemble of their own without the aid of other instruments. This necessitated an extension of the band's compass to three complete octaves, and musicians of renown were now invited to contribute some of their compositions.

Among those who were so honored was Johann Gumpenhuber, a virtuoso attached to the Imperial Chapel. The instrument on which he excelled was the pantaleon, a sort of large tympanon or dulcimer with gut and wire strings, invented about 1690 by his teacher Pantaleon Hebenstreit. This German musician, also a violinist of renown, found himself in Paris in 1705, and having been presented to Louis XIV, he played on his newly invented instrument at Versailles before the Grande Monarche and his court. The King was delighted and forthwith baptized the instrument by Hebenstreit's first name, "Pantaleon."

In 1757, two years after the founding at the center of the empire, of the University of Moscow by Elizabeth's young favorite, Ivan Schouvaloff, Naryshkin organized a grand hunt in honor of the Empress, and gave a concert with his hunting band in the gardens surrounding the hunting lodge of Izmayloff, a suburb of 
Moscow, before Elizabeth and her court. The affair was a great success and Elizabeth so well pleased that she appointed Naryshkin master of the hounds and ordered a similar band to be formed at once for her. So the band heretofore recognized as Naryshkin's hunting music, became known as the Music of the Imperial Hunt, and Maresch was appointed Kapellmeister with an increased financial remuneration as reward for his untiring efforts.

The successful development of the band was rapid, and following a false conception, the Music of the Imperial Hunt was employed to accompany Hermann F. Raupach's opera "Alcesta," given at Petrograd in 1779, where the composer had been appointed by Catharine II orchestral director of the opera.

Historians who have written on the subject of these horns have expressed widely divergent opinions; some claiming that these instruments were of wood, others again maintaining that they were of brass! It was in 1779, however, that the brass horns were replaced by wooden horns covered with brass; they were straight, and lackered on the inside, which was supposed to render their tone more soft, making it possible to use them oftener in place of ensembles made up of clarinets, French horns, bassoons, etc. The making of these hunting horns was confided to expert workmen, and their manufacture was quite expensive. To overcome the greatest difficulty, that of perfect attunement, Maresch added a tube to the lower end of each instrument which made it possible to lengthen or shorten it, consequently to get it in tune.

Among the pieces played by the Music of the Imperial Hunt were the overtures to "Henry IV" (Martini), "The Deserter" (Monsigny), "La Belle Arsène" (Monsigny), "Le Tableau Parlant" (Grétry), "Le Marchand de Smyrne" (Haindl) and "Zemire et Azor" (Grétry), while fugues for four voices were given with a precision that no organist could excell.

The drawing here given is taken from "Entstehung, Fortgang and jetrige Beschaffenheit der Russischen Jagdmusik," by Johann Christian Hinrichs. Born in Hamburg in 1760, Hinrichs went to Russia when about twenty years of age, and in time became known as Hinrichs, professor at the School of Statistics founded by the Government; the book referred to came out in Petrograd in 1796 when the Russian Hunting Music reached its highest point of excellence. The large folio of xiv and 24 pages was published by one Schnorr; it contains plates presenting pictures of the instruments and their description, the tablature in score and examples of music. In addition, it has a biography of Maresch. 
The story is told of Joseph $\Pi$, he who benefited by the dismemberment of Poland: when on a visit to Peterhof, the Tsar's residence near Petrograd, he heard for the first time the Russian horns, and was startled by the effect they produced. He desired to have Maresch presented to him, and after listening to a thorough explanation of the mechanism of his music, the Emperor tapped him familiarly on the shoulder, exclaiming: "Bravo! that's fine! Only you require forty men for this work which I can accomplish with one man, playing the organ. But then you have here numbers of men, enough to form easily a couple of companies!"

About 1796 there were nine bands of hunting music in Petrograd, among which were those of Prince Patiomkin and Wadkovskoi. Russian Hunting Music was heard in 1817 at Mannheim in a most successful rendition of a Te Deum; another similar band was heard in Paris toward the end of 1833 in the hall of the "Concerts Montesquieu."

This music of the Imperial Hunt is certainly the most remarkable musical curiosity of the eighteenth century from Russia. Its merit lies entirely with the Bohemian Maresch, a celebrated man one hundred and fifty years ago, but to-day entirely forgotten and seldom mentioned even in biographical dictionaries. 